\title{
Detection of Tetracycline Resistance Genes in European Hedgehogs (Erinaceus europaeus) and Crested Porcupines (Hystrix cristata)
}

\author{
Borel, Nicole ; Marti, Hanna ; Di Francesco, A ; Renzi, M ; Salvatore, D
}

\begin{abstract}
Relatively little is known regarding the role of wildlife in the development of antibiotic resistance. Our aim was to assess the presence of the tetracycline resistance genes, tet(A), tet(B), tet(C), tet(D), tet(E), tet(G), tet(K), tet $(\mathrm{L})$, tet $(\mathrm{M})$, tet $(\mathrm{O})$, tet $(\mathrm{P})$, tet $(\mathrm{Q})$, tet $(\mathrm{S})$, and tet $(\mathrm{X})$, in tissue samples of 14 hedgehogs (Erinaceus europaeus) and 15 crested porcupines (Hystrix cristata) using PCR assays. One or more tet genes were found in all but three hedgehogs and one crested porcupine. Of the 14 tetracycline resistance genes investigated, 13 were found in at least one sample; tet $(\mathrm{G})$ was not detected. We confirmed the potential role of wild animals as bioindicators, reservoirs, or vectors of antibiotic-resistant bacteria in the environment.
\end{abstract}

DOI: https://doi.org/10.7589/2019-03-068

Posted at the Zurich Open Repository and Archive, University of Zurich

ZORA URL: https://doi.org/10.5167/uzh-184306

Journal Article

Published Version

Originally published at:

Borel, Nicole; Marti, Hanna; Di Francesco, A; Renzi, M; Salvatore, D (2020). Detection of Tetracycline Resistance Genes in European Hedgehogs (Erinaceus europaeus) and Crested Porcupines (Hystrix cristata). Journal of Wildlife Diseases, 56(1):219-223.

DOI: https://doi.org/10.7589/2019-03-068 


\title{
SHORT COMMUNICATIONS
}

\section{Detection of Tetracycline-resistance Genes in European Hedgehogs (Erinaceus europaeus) and Crested Porcupines (Hystrix cristata)}

\begin{abstract}
Antonietta Di Francesco,,${ }^{1,4}$ Maria Renzi, ${ }^{2}$ Nicole Borel, ${ }^{3}$ Hanna Marti, ${ }^{3}$ and Daniela Salvatore ${ }^{1} \quad{ }^{1}$ Department of Veterinary Medical Sciences, University of Bologna, Ozzano dell'Emilia, Bologna, Italy; ${ }^{2}$ Istituto Zooprofilattico della Lombardia e dell'Emilia Romagna, sezione di Bologna, Bologna, Italy; ${ }^{3}$ Institute of Veterinary Pathology, Vetsuisse Faculty, University of Zurich, CH-8057, Zurich, Switzerland; ${ }^{4}$ Corresponding author (email: antoniet.difrancesco@ unibo.it)
\end{abstract}

ABSTRACT: Relatively little is known regarding the role of wildlife in the development of antibiotic resistance. Our aim was to assess the presence of the tetracycline resistance genes, tet $(\mathrm{A}), \operatorname{tet}(\mathrm{B})$, tet $(\mathrm{C}), \operatorname{tet}(\mathrm{D}), \operatorname{tet}(\mathrm{E}), \operatorname{tet}(\mathrm{G}), \operatorname{tet}(\mathrm{K}), \operatorname{tet}(\mathrm{L})$, tet $(\mathrm{M})$, tet $(\mathrm{O})$, tet $(\mathrm{P})$, tet $(\mathrm{Q})$, tet $(\mathrm{S})$, and tet $(\mathrm{X})$, in tissue samples of 14 hedgehogs (Erinaceus europaeus) and 15 crested porcupines (Hystrix cristata) using polymerase chain reaction (PCR) assays. One or more tet genes were found in all but three hedgehogs and one crested porcupine. Of the 14 tetracycline resistance genes investigated, 13 were found in at least one sample; tet $(\mathrm{G})$ was not detected. We confirmed the potential role of wild animals as bioindicators, reservoirs, or vectors of antibiotic-resistant bacteria in the environment.

Key words: Antimicrobial resistance, Erinaceus europaeus, Hystrix cristata, PCR, tetracycline resistance genes.

The tetracyclines are one of the most widely used classes of antimicrobial agents in human and veterinary medicine and agriculture due to their broad spectrum of activity, low cost, oral administration, and the occurrence of few side effects. The widespread use of tetracyclines has subjected bacterial populations to selection pressure and increased the prevalence of tetracycline resistance, one of the most abundant antibiotic resistances among pathogenic and commensal microorganisms. Tetracycline resistance is generally caused by the acquisition of tetracycline resistance (tet) genes, identified in environmental and animal- and aquaculture-associated bacteria. Three main resistance mechanisms are coded by tet genes: active efflux pumps, ribosomal protection, and enzyme inactivation. The first two mechanisms currently predominate in clinical settings (Roberts 2005).

The spread of antimicrobial resistance (AMR) has commonly been attributed to clinical or farming overuse of antimicrobials.
Nevertheless, AMR has also been reported in the absence of antimicrobial treatments, as in wild animals such as deer (Carroll et al. 2015), wild rodents (Furness et al. 2017), wild boars (Sus scrofa; Poeta et al. 2007), wolves (Gonçalves et al. 2013a), lynxes (Gonçalves et al, 2013b), red foxes (Vulpes vulpes; Radhouani et al. 2013), wild rabbits (Figueiredo et al. 2009), and birds (Sato et al. 1978).

Small wild mammals are considered to be environmental bioindicators because they are affected by changes in their habitat and by environmental contaminants, thus enabling the detection of environmental trends. In this regard, the potential role of the hedgehog as a bioindicator for environmental contamination from organochlorine compounds, heavy metals, and anticoagulant rodenticides has been reported (Alleva et al. 2006; D'Havé et al. 2007; Dowding et al. 2010). With respect to AMR, small wild mammals have been documented to frequently interact with sources of human and agricultural waste (Radhouani et al. 2014), and are thus potentially exposed to anthropogenic sources of AMR in the environment.

The aim of this study was to evaluate the presence of 14 tetracycline resistance genes in tissue samples from 14 European hedgehogs (Erinaceus europaeus) and 15 crested porcupines (Hystrix cristata) using polymerase chain reaction (PCR). Eight of the 14 hedgehogs and all the crested porcupines were from the Emilia Romagna region (Northern Italy), collected at a wildlife recovery center from October 2017 to March 2018, then submitted to the Bologna section of the Lombardy and Emilia-Romagna Experimental Zootechnic Institute for investigation within a regional monitoring plan for 
wildlife. Most of the animals showed limb fracture, head trauma (presumably due to road accidents), pulmonary congestion, or cachexia. We extracted DNA from 75 samples of organs such as the intestine, liver, spleen, kidney and lung, using a commercial kit (DNA mini kit, Qiagen, Hilden, Germany) and following the manufacturer's recommendations. One extraction control was also included consisting of kit reagents only. Regarding the remaining six hedgehogs, DNA extracted from 13 formalin-fixed and paraffin-embedded (Burach et al. 2014) tissue pools or organs was provided by the Institute of Veterinary Pathology (University of Zurich, Switzerland). Of those six hedgehogs, five were from the Zurich region and one was from the canton of Valais.

In total, 88 DNA samples were tested for 14 tetracycline resistance genes involved in the three tetracycline resistance mechanisms: tet $(\mathrm{A}), \operatorname{tet}(\mathrm{B}), \operatorname{tet}(\mathrm{C}), \operatorname{tet}(\mathrm{D}), \operatorname{tet}(\mathrm{E}), \operatorname{tet}(\mathrm{G})$, tet $(\mathrm{K})$, tet $(\mathrm{L}), \operatorname{tet} A(\mathrm{P})$ in the active efflux, tet $(\mathrm{M}), \operatorname{tet}(\mathrm{O}), \operatorname{tet}(\mathrm{Q}), \operatorname{tet}(\mathrm{S})$ in the ribosomal protection, and tet $(\mathrm{X})$ in the enzymatic inactivation. We carried out PCR using primers described by $\mathrm{Ng}$ et al. (2001). The DNA extracted from Escherichia coli field strains, containing tetracycline resistance plasmids, was used as a positive control. The extraction control and a distilled water negative control were also included. The amplicons were purified using a QIAquick PCR purification kit (Qiagen), and both DNA strands were sequenced (Bio-Fab Research, Rome, Italy). The sequences obtained were compared with the public sequences available using the BLAST server in GenBank (National Center for Biotechnology Information 2018).

Of the 23 animals tested from Italy (fresh samples), 100\% (8/8) hedgehogs and 93\% (14/ $15)$ of the crested porcupines were positive for one or more tet genes (Table 1), with an average number of 4.2 tet genes per animal. Of the Swiss hedgehogs (formalin-fixed samples), $50 \%$ (3/6) were positive for one or more tet genes, with an average number of 0.7 tet genes per animal (Table 2).
Thirteen of the 14 tet genes were found in at least one sample. The tet $(\mathrm{G})$ gene was not detected. The tet $(\mathrm{M})$ gene was found in $52 \%$ (15/29) animals, being the most commonly detected tet gene, followed by $t e t(\mathrm{~K})$ and tet $(\mathrm{X})$, both at $41 \%(12 / 29)$. With respect to the samples tested, tet $(\mathrm{X})$ was found in $32 \%$ (28/88) samples, followed by tet $(\mathrm{M})$ which was found in $31 \%(27 / 88)$.

For each tet gene amplified, the identity of the amplicon was confirmed by the comparison between the sequence obtained and the corresponding sequences from antibioticresistant gram-positive or gram-negative bacteria in the GenBank database, showing 99$100 \%$ nucleotide similarity. One sequence for each of the 13 tetracycline resistance genes amplified was deposited in the GenBank database under accession numbers MH837952 to MH837964.

The results of the present study confirmed that small wild mammals may function as sentinels, environmental reservoirs, or potential vectors of antibiotic-resistant bacteria or resistance genes in the environment and transmission to other hosts, including humans. A very high gene prevalence was highlighted in the fresh samples both from hedgehogs and porcupines, while a low tet prevalence was observed in formalin-fixed samples, probably due to the fixation process which is known to exhibit nucleic acid degradation (Feldman 1973).

Small mammals could acquire antimicrobials, antimicrobial residues, resistant bacteria, or mobile genetic elements from humaninfluenced habitats. Additional selection pressures for antibiotic resistance in natural microbial communities could occur, taking into account that most antibiotics are produced by strains of fungi and bacteria that occur naturally in all environments, including soil (Martin and Liras 1989).

All the inner organs tested in addition to the intestine were positive at least once for one or more tet genes. Most of the culture-based studies focused on the antibiotic resistance gene reservoir of the gut microbiota, gut communities constituting a very large reservoir of resistance genes for pathogens. Taking 
TABLE 1. Tetracycline resistance genes polymerase chain reaction (PCR) detected in tissue samples from Italian hedgehogs (Erinaceus europaeus) and crested porcupines (Hystrix cristata), October 2017-March 2018.

\begin{tabular}{|c|c|c|c|c|c|}
\hline \multicolumn{3}{|c|}{ Animal } & \multicolumn{3}{|c|}{ Animal } \\
\hline Hedgehog & Samples & tet genes detected & Crested porcupine & Samples & tet genes detected \\
\hline \multirow[t]{3}{*}{ CLET-185454 } & Intestine & $\begin{array}{c}\mathrm{A}, \mathrm{B}, \mathrm{C}, \mathrm{D}, \mathrm{E}, \mathrm{K} \\
\mathrm{L}, \mathrm{M}, \mathrm{P}, \mathrm{Q}, \mathrm{S}\end{array}$ & CLET-31022 & Intestine & $\begin{array}{l}\mathrm{B}, \mathrm{D}, \mathrm{E}, \mathrm{M}, \mathrm{O}, \mathrm{P}, \mathrm{Q} \\
\quad \mathrm{S}, \mathrm{X}\end{array}$ \\
\hline & Kidney & $\mathrm{M}, \mathrm{P}, \mathrm{X}$ & & Kidney & $\mathrm{B}, \mathrm{D}, \mathrm{E}, \mathrm{O}, \mathrm{P}, \mathrm{Q}, \mathrm{S}, \mathrm{X}$ \\
\hline & Liver & None & & Liver & $\mathrm{B}, \mathrm{C}, \mathrm{M}, \mathrm{O}, \mathrm{P}, \mathrm{Q}, \mathrm{S}, \mathrm{X}$ \\
\hline \multirow[t]{3}{*}{ CLET-221812 } & Intestine & $\mathrm{B}, \mathrm{L}, \mathrm{M}, \mathrm{O}, \mathrm{P}, \mathrm{X}$ & CLET-351020 & Intestine & None \\
\hline & Kidney & None & & Kidney & None \\
\hline & Liver & $\mathrm{A}, \mathrm{B}, \mathrm{P}, \mathrm{X}$ & & Liver & None \\
\hline \multirow[t]{3}{*}{ CLET-271251 } & Kidney & $\mathrm{L}, \mathrm{M}, \mathrm{O}, \mathrm{P}, \mathrm{X}$ & & Spleen & $\mathrm{M}, \mathrm{O}$ \\
\hline & Liver & $\mathrm{P}$ & CLET-64411 & Intestine & $\mathrm{M}, \mathrm{O}$ \\
\hline & Spleen & $\mathrm{L}, \mathrm{M}, \mathrm{P}, \mathrm{X}$ & & Kidney & $\mathrm{O}$ \\
\hline \multirow[t]{5}{*}{ CLET-281290 } & Intestine & $\mathrm{A}, \mathrm{K}, \mathrm{L}, \mathrm{M}, \mathrm{O}$ & & Liver & None \\
\hline & Kidney & $\mathrm{L}, \mathrm{M}, \mathrm{O}, \mathrm{S}, \mathrm{X}$ & CLET-51993 & Intestine & M \\
\hline & Liver & $\mathrm{L}, \mathrm{M}, \mathrm{O}, \mathrm{S}, \mathrm{X}$ & & Kidney & None \\
\hline & Spleen & $\mathrm{L}, \mathrm{M}, \mathrm{O}, \mathrm{S}, \mathrm{X}$ & & Liver & None \\
\hline & Lung & $\mathrm{M}, \mathrm{S}, \mathrm{X}$ & & Lung & $\mathrm{M}, \mathrm{O}$ \\
\hline \multirow[t]{4}{*}{ CLET-281299 } & Intestine & $\mathrm{A}, \mathrm{B}, \mathrm{K}, \mathrm{L}, \mathrm{M}$ & CLET-107784 & Intestine & $\mathrm{O}$ \\
\hline & Kidney & $\mathrm{X}$ & & Kidney & $\mathrm{O}, \mathrm{Q}, \mathrm{X}$ \\
\hline & Liver & $\mathrm{X}$ & & Liver & $\mathrm{O}, \mathrm{Q}$ \\
\hline & Lung & $\mathrm{M}, \mathrm{X}$ & CLET-10306 & Intestine & $\mathrm{A}, \mathrm{B}, \mathrm{D}$ \\
\hline \multirow[t]{3}{*}{ CLET-126934 } & Intestine & $\mathrm{K}, \mathrm{L}, \mathrm{M}$ & & Kidney & $\mathrm{A}, \mathrm{B}, \mathrm{D}, \mathrm{K}$ \\
\hline & Kidney & $\mathrm{K}, \mathrm{L}, \mathrm{M}$ & & Liver & A, B \\
\hline & Liver & $\mathrm{K}, \mathrm{L}$ & CLET-92193 & Intestine & $\mathrm{K}, \mathrm{L}, \mathrm{M}$ \\
\hline \multirow[t]{3}{*}{ CLET-175472 } & Intestine & $A, B, D, X$ & & Kidney & $\mathrm{K}, \mathrm{L}, \mathrm{M}$ \\
\hline & Kidney & $\mathrm{X}$ & & Liver & K \\
\hline & Liver & $\mathrm{X}$ & & Lung & $\mathrm{K}, \mathrm{L}, \mathrm{M}$ \\
\hline \multirow[t]{3}{*}{ CLET-193051 } & Intestine & $\mathrm{A}, \mathrm{B}, \mathrm{X}$ & CLET-60428 & Intestine & None \\
\hline & Kidney & $A, B, X$ & & Kidney & None \\
\hline & Liver & None & & Liver & None \\
\hline
\end{tabular}

TABLE 2. Tetracycline resistance genes polymerase chain reaction (PCR) detected in formalin-fixed and paraffin-embedded tissue pools or organs from Swiss hedgehogs (Erinaceus europaeus), March 2018.

\begin{tabular}{|c|c|c|}
\hline Animal & Samples & tet genes detected \\
\hline \multirow[t]{3}{*}{ S16-1350 } & Pool 1 (lung-kidney- spleen) & None \\
\hline & Pool 2 (heart-liver) & None \\
\hline & Brain & None \\
\hline \multirow[t]{3}{*}{ S16-1383 } & Pool 1 (liver-brain-small intestine-spleen) & None \\
\hline & Pool 2 (small intestine-pancreas-kidney-lymph nodes-lung) & None \\
\hline & Pool 3 (heart-lung-kidney-uterus-large intestine-bone marrow) & None \\
\hline \multirow[t]{2}{*}{ S16-1431 } & Lung & $\mathrm{K}$ \\
\hline & Pool (liver-spleen-kidney-lymph nodes) & None \\
\hline \multirow[t]{2}{*}{ S16-1541 } & Pool 1 (liver-spleen-kidney-lung-nasal conchae) & $\mathrm{A}, \mathrm{K}$ \\
\hline & Pool 2 (heart-brain-stomach) & A \\
\hline S16-1740 & Pool (brain-lung) & $\mathrm{P}$ \\
\hline \multirow[t]{2}{*}{ S16-1746 } & Pool 1 (brain-eye-diaphragm) & None \\
\hline & Pool 2 (lung-kidney-liver-intestine-heart-spleen) & None \\
\hline
\end{tabular}


into account that our molecular approach did not allow the association of tet genes to bacterial hosts, we considered the detection of tet genes in inner organs as suggestive of their association to bacteria responsible for infection in the animals tested. We excluded contamination from intestinal contents because the intestines of the animals tested were intact and the DNA extraction was performed by removing an internal fragment from each organ with a disposable scalpel blade. In addition, different tet genes between intestine and other organs were identified in more than one animal.

A high gene diversity for antibiotic resistance was identified, tet $(\mathrm{M})$ and tet $(\mathrm{X})$ genes exhibiting the highest rate of occurrence among tet genes in the animals and tissue samples, respectively. With respect to the prevalence of tet $(\mathrm{M})$ gene, the results of the present study were consistent with other reports showing a wide distribution of $t e t(\mathrm{M})$ among both gram-negative and gram-positive bacteria (Roberts 2005). Interestingly, our results showed a high frequency of tet $(\mathrm{X})$, responsible for the enzymatic inactivation of the tetracycline molecule, which has long been considered as a rare resistance mechanism. Little research has been conducted on tet $(\mathrm{X})$ because this gene is not considered clinically relevant. However, recent studies, most of which associated with the environment (Forsberg et al. 2015), suggest that the enzymatic inactivation mechanism for tetracycline resistance should not be neglected and merits further investigation. Finally, the negative result for we obtained for tet $(\mathrm{G})$ was not surprising, according to the low prevalence reported in literature (Pons et al. 2018).

We used a culture-independent approach to detect AMR genes in hedgehogs and crested porcupines. Recent studies have directly investigated the presence of resistance genes by molecular analysis (BlancoPeña et al. 2017). Generally used diagnostic methods involve bacterial culture and subsequent detection of AMR specifically attributed to a microbial isolate. Faced with the high specificity of culturing, a possible underestimation of the AMR occurrence could occur, due to a consistent nonculturable fraction of microorganisms. Singer et al. (2007) suggested that there was excessive focus on resistant organisms and not enough on resistance genes in ecological studies of antimicrobial resistance, taking into account the capability of bacteria to transfer resistance genes. Considering AMR genes as environmental contaminants, methods which allow searching for these genes directly rather than for the bacteria carrying them could help in efficiently investigating the spread of AMR in all the components (Vittecoq et al. 2016).

\section{LITERATURE CITED}

Alleva E, Francia N, Pandolfi M, De Marinis AM, Chiarotti F, Santucci D. 2006. Organochlorine and heavy-metal contaminants in wild mammals and birds of Urbino-Pesaro Province, Italy: An analytic overview for potential bioindicators. Arch Environ Contam Toxicol 51:123-134.

Blanco-Peña K, Esperón F, Torres-Mejía AM, de la Torre A, de la Cruz E, Jiménez-Soto M. 2017. Antimicrobial resistance genes in pigeons from public parks in Costa Rica. Zoonoses Public Health 64:e23-e30.

Burach F, Pospischil A, Hanger J, Loader J, Pillonel T, Greub G, Borel N. 2014. Chlamydiaceae and chlamydia-like organisms in the koala (Phascolarctos cinereus)_Organ distribution and histopathological findings. Vet Microbiol 172:230-240.

Carroll D, Wang J, Fanning S, McMahon BJ. 2015. Antimicrobial resistance in wildlife: Implications for public health. Zoonoses Public Health 62:534-542.

D'Havé H, Scheirs J, Covaci A, van den Brink NW, Verhagen R, De Coen W. 2007. Non-destructive pollution exposure assessment in the European hedgehog (Erinaceus europaeus): IV. Hair versus soil analysis in exposure and risk assessment of organochlorine compounds. Environ Pollut 145:861-868.

Dowding CV, Shore RF, Worgan A, Baker PJ, Harris S. 2010. Accumulation of anticoagulant rodenticides in a non-target insectivore, the European hedgehog (Erinaceus europaeus). Environ Pollut 158:161-166.

Feldman MY. 1973. Reactions of nucleic acids and nucleoproteins with formaldehyde. Prog Nucleic Acid Res Mol Biol 13:1-49.

Figueiredo N, Radhouani H, Gonçalves A, Rodrigues J, Carvalho C, Igrejas G, Poeta P. 2009. Genetic characterization of vancomycin-resistant enterococci isolates from wild rabbits. J Basic Microbiol 49:491494.

Forsberg KJ, Patel S, Wencewicz TA, Dantas G. 2015. The tetracycline destructases: A novel family of tetracycline-inactivating enzymes. Chem Biol 22: 888-897. 
Furness LE, Campbell A, Zhang L, Gaze WH, McDonald RA. 2017. Wild small mammals as sentinels for the environmental transmission of antimicrobial resistance. Environ Res 154:28-34.

Gonçalves A, Igrejas G, Radhouani H, Correia S, Pacheco R, Santos T, Monteiro R, Guerra A, Petrucci-Fonseca F, Brito F, et al. 2013a. Antimicrobial resistance in faecal enterococci and Escherichia coli isolates recovered from Iberian wolf. Lett Appl Microbiol 56:268-274.

Gonçalves A, Igrejas G, Radhouani H, Santos T, Monteiro R, Pacheco R, Alcaide E, Zorrilla I, Serra R, Torres C, et al. 2013b. Detection of antibiotic resistant enterococci and Escherichia coli in free range Iberian Lynx (Lynx pardinus). Sci Total Environ 456-457: 115-119.

Martín MF, Liras P. 1989. Organization and expression of genes involved in the biosynthesis of antibiotics and other secondary metabolites. Annu Rev Microbiol 43: 173-206.

National Center for Biotechnology Information. 2019. Basic local alignment search tool (BLAST). http:// blast.ncbi.nlm.nih.gov/Blast.cgi. Accessed July 2018.

Ng LK, Martin I, Alfa M, Mulvey M. 2001. Multiplex PCR for the detection of tetracycline resistant genes. Mol Cell Probes 15:209-215.

Poeta P, Costa D, Igrejas G, Rojo-Bezares B, Sáenz Y, Zarazaga M, Ruiz-Larrea F, Rodrigues J, Torres C. 2007. Characterization of vanA-containing Enterococcus faecium isolates carrying Tn5397-like and Tn916/Tn1545-like transposons in wild boars (Sus scrofa). Microb Drug Resist 13:151-156.
Pons MJ, de la Peña AT, Mensa L, Martón P, RuizRoldán L, Martínez-Puchol S, Vila J, Gascón J, Ruiz J. 2018. Differences in tetracycline resistance determinant carriage among Shigella flexneri and Shigella sonnei are not related to different plasmid Inc-type carriage. J Glob Antimicrob Resist 13:131-134.

Radhouani H, Igrejas G, Gonçalves A, Pacheco R, Monteiro R, Sargo R, Brito F, Torres C, Poeta P. 2013. Antimicrobial resistance and virulence genes in Escherichia coli and enterococci from red foxes (Vulpes vulpes). Anaerobe 23:82-86.

Radhouani H, Silva N, Poeta P, Torres C, Correia S, Igrejas G. 2014. Potential impact of antimicrobial resistance in wildlife, environment and human health. Front Microbiol 5:23.

Roberts MC. 2005. Update on acquired tetracycline resistance genes. FEMS Microbiol Lett 245:195-203.

Sato G, Oka C, Asagi M, Ishiguro N. 1978. Detection of conjugative $\mathrm{R}$ plasmids conferring chloramphenicol resistance in Escherichia coli isolated from domestic and feral pigeons and crows. Zentralbl Bakteriol Orig A 241:407-417.

Singer RS, Ward MP, Maldonado G. 2007. Can landscape ecology untangle the complexity of antibiotic resistance? Nat Rev Microbiol 4:943-952.

Vittecoq M, Godreuil S, Prugnolle F, Durand P, Brazier L, Renaud N, Arnal A, Aberkane S., Jean-Pierre H., Gauthier-Clerc M, et al. 2016. Antimicrobial resistance in wildlife. J Appl Ecol 53:519-529.

Submitted for publication 20 March 2019.

Accepted 8 May 2019. 